\title{
PERMIAN SPHINCTOZOAN SPONGES FROM THE LOWER AND MIDDLE CAPITAN FORMATION, WEST TEXAS AND NEW MEXICO
}

JOHNS*, Ronald A., Math/Science Div., Austin Community College, 1020 Grove Blvd., Austin, TX 78741; KIRKLAND-GEORGE, Brenda, Dept. of Geol. Sciences, Univ. of Texas at Austin, Austin, TX 78712

The Capitan reef complex of West Texas and New Mexico represents the best-preserved Permian reef in the world. Dominated by sphinctozoan sponges and bound by algae and microbialite, the massive member of the Capitan Formation most likely developed as a barrier reef along the margin of the Delaware Basin. While the facies relationships and depositional setting have been intensively studied, very little has been done on the organisms that comprise the reef itself.

Because the lower and middle Capitan biota remain relatively unknown, we have initiated a study of taxonomy, faunal diversity, and ecological relationships within these units. Samples from the lower and middle Capitan Formation were collected and analyzed from Big Canyon, Black Canyon, Gunsight Canyon, Slaughter Canyon and North McKittrick Canyon. Dolomitization has largely destroyed the reef fabric of the lowest part of the Capitan in the first three localities, but about two dozen slightly dolomitized small blocks were collected from the lower and middle Capitan in Slaughter and North McKittrick Canyons.

In this preliminary analysis, six taxa of calcareous sponge were recognized from the lower Capitan. Cystothalamia and Lemonea are the most abundant genera, but Guadalupia is also common. Other taxa include Amblysiphonella, Discosiphonella, and Ambithalamia, the latter genus only having been previously described from Permian reefs in Thailand.

Seven species in five genera have been identified from the middle Capitan. These include two species each of Amblysiphonella and Lemonea, as well as representatives of Girtyocoelia, Guadalupia, and more questionably, Uvothalamia.

While the current analysis is still in its early stages, it nevertheless appears that sponge diversity decreased towards the top of the Capitan Formation, either as a result of changes in environmental conditions or as the gradual increase in extinction towards the end of the Paleozoic Era. 